\title{
Lactobacillus durianis sp. nov., isolated from an acid-fermented condiment (tempoyak) in Malaysia
}

\footnotetext{
1 Department of Veterinary Microbiology, Royal Veterinary and Agricultural University, Stigbøjlen 4, 1870 Frederiksberg C., Copenhagen, Denmark

2 BCCM/LMG Bacteria Collection, Laboratory of Microbiology, University of Ghent, K. L. Ledeganckstraat 35, B-9000 Ghent, Belgium

${ }^{3}$ Department of Food Science, Universiti Putra Malaysia, 43400 Serdang, Selangor DE, Malaysia
}

\author{
J. J. Leisner, ${ }^{1} \mathrm{M}$. Vancanneyt, ${ }^{2} \mathrm{~K}$. Lefebvre, ${ }^{2} \mathrm{~K}$. Vandemeulebroecke, ${ }^{2}$ \\ B. Hoste, ${ }^{2}$ N. Euras Vilalta, ${ }^{1}$ G. Rusul ${ }^{3}$ and J. Swings ${ }^{2}$
}

\author{
Author for correspondence: Jørgen Leisner. Tel: +45 3528 2768. Fax: +45 35282757. \\ e-mail:jjl@kvl.dk
}

\begin{abstract}
Lactic acid bacteria (LAB) are the predominant micro-organisms in tempoyak, a Malaysian acid-fermented condiment. In a study on the diversity of LAB in this product, three isolates could not be identified using SDS-PAGE of whole-cell proteins or API $50 \mathrm{CH}$. The taxonomic position of the three isolates was clarified in the present study. $16 \mathrm{~S}$ rDNA sequencing classified a representative strain in the genus Lactobacillus, clearly separated from all known species, and most closely related to the Lactobacillus reuteri phylogenetic group. DNA-DNA hybridization experiments and an extensive phenotypic description confirm that the strains represent a single and separate novel species among the obligately heterofermentative lactobacilli. The three isolates are distinguished at the intra-species level by plasmid profiling, pulsed-field gel electrophoresis of macro-restriction fragments and biochemical features. The name Lactobacillus durianis sp. nov. is proposed for the novel taxon and the type strain is LMG $19193^{\top}$ ( = CCUG 45405').
\end{abstract}

Keywords: lactic acid bacteria, identification, tempoyak, durian fruit, Malaysia

\section{INTRODUCTION}

During a study on the biodiversity of lactic acid bacteria (LAB) from a traditional Malaysian acidfermented condiment, tempoyak, three similar strains were isolated that could not be identified to the species level when applying SDS-PAGE of whole-cell proteins or API $50 \mathrm{CH}$ strips (Leisner et al., 2001). In a polyphasic approach, the three strains were studied extensively and it was found that they constitute a novel species that is described in the present paper.

\section{METHODS}

Bacterial strains. Strains LMG 19193 and LMG 19196 were isolated from a single batch of tempoyak and strain LMG 19195 from a second batch, both obtained from the same producer at a night market in Serdang, Selangor DE, Malaysia. The isolation procedure of the isolates has been described previously (Leisner et al., 2001). All three strains were deposited in the BCCM/LMG Bacteria Collection (http://www/belspo.be/bccm/lmg.htm).

Abbreviation: $L A B$, lactic acid bacteria.

The EMBL accession number for the $16 \mathrm{~S}$ rDNA sequence of strain LMG $19193^{\top}$ is AJ315640.
16S rDNA sequence analysis. Genomic DNA of strain LMG $19193^{\mathrm{T}}$ was extracted by using the DNA isolation protocol of Niemann et al. (1997). A fragment of the 16S rDNA (corresponding to positions 8-1541 in the Escherichia coli numbering system) was amplified by PCR using the conserved primers pA (5'-AGAGTTTGATCCTGGCTCAG$\left.3^{\prime}\right)$ and $\mathrm{pH}\left(5^{\prime}\right.$-AAGGAGGTGATCCAGCCGCA-3'). The PCR product was purified using a Qiaquick PCR purification kit (Qiagen), according to the manufacturer's instructions. Sequencing was performed using an Applied Biosystems 377 DNA Sequencer and the protocols of the manufacturer using the ABI Prism Dye Terminator Cycle Sequencing ready reaction kit. The eight sequencing primers used are listed in Coenye et al. (1999). Sequence assembly was performed by using the program AUTOASSEMBLER (Applied Biosystems). Phylogenetic analysis was performed using the BIONUMERICS software package (Applied Maths) after including the consensus sequence in an alignment of small ribosomal subunit sequences collected from the international nucleotide sequence library EMBL. This alignment was calculated pairwise using an open gap penalty of $100 \%$ and a unit gap penalty of $0 \%$. A similarity matrix was created by homology calculation with a gap penalty of $0 \%$; unknown bases were discarded. The resulting tree was constructed using the neighbour-joining method.

DNA base compositions. High-molecular-mass native DNA was prepared from strains LMG 19193 ${ }^{\mathrm{T}}$ and LMG 19196. 
Cells were cultivated in MRS broth (Oxoid) for $24 \mathrm{~h}$ at $28{ }^{\circ} \mathrm{C}$. DNA was extracted from $0 \cdot 75-1.25 \mathrm{~g}$ wet weight of cells using the protocol described by Pitcher et al. (1989) with the following modifications: the washed cell pellet was resuspended and lysed in a buffer $(10 \mathrm{mM}$ Tris $/ \mathrm{HCl}$, $100 \mathrm{mM}$ EDTA, pH 8.0) containing RNase $\left(200 \mu \mathrm{g} \mathrm{ml}^{-1}\right.$; Sigma), proteinase K $\left(500 \mu \mathrm{g} \mathrm{ml}^{-1}\right.$; Merck) and lysozyme (50 $\mathrm{mg} \mathrm{ml}^{-1}$; SERVA) for $1 \mathrm{~h}$ at $37^{\circ} \mathrm{C}$ before the addition of GES reagent. DNA was enzymically degraded into nucleosides as described by Mesbah et al. (1989). The nucleoside mixture obtained was then separated by HPLC using a Waters SymmetryShield C8 column thermostatted at $37^{\circ} \mathrm{C}$. The solvent was $0.02 \mathrm{M} \mathrm{NH}_{4} \mathrm{H}_{2} \mathrm{PO}_{4}(\mathrm{pH} 4.0)$ with $1.5 \%$ acetonitrile. Non-methylated lambda phage DNA (Sigma) was used as the calibration reference.

DNA-DNA hybridization experiments. High-molecular-mass native DNA was prepared as described above for determination of the DNA base composition. DNA-DNA hybridizations were performed with photobiotin-labelled probes in microplate wells as described by Ezaki et al. (1989), using a HTS7000 Bio Assay Reader (Perkin Elmer) for the fluorescence measurements. Biotinylated DNA was hybridized with single-stranded unlabelled DNA, non-covalently bound to microplate wells. Hybridizations were performed at $40{ }^{\circ} \mathrm{C}$ in hybridization mixture $(2 \times \mathrm{SSC}, 5 \times$ Denhardt's solution, $2.5 \%$ dextran sulfate, $50 \%$ formamide, $100 \mu \mathrm{g}$ denatured salmon sperm DNA ml-1, $1250 \mathrm{ng}$ biotinylated probe DNA ml ${ }^{-1}$ ).

Biochemical and physiological tests. Cell morphology and motility were examined using phase-contrast microscopy on cultures grown in All-Purpose-Tween broth (APT; Difco Laboratories, 1984) with glucose $\left(10 \mathrm{~g}^{-1}\right)$ or glucose plus D-xylose (both $10 \mathrm{~g}^{-1}$ ) as substrates. Under the same conditions, growth was tested at different temperatures $(7,10$, $15,21,25,30,37,42$ and $45^{\circ} \mathrm{C}$ ). Growth at different salinities (APT agar containing 6.5 or $8 \% \mathrm{NaCl}$ ) was tested at $30{ }^{\circ} \mathrm{C}$. The strains were tested for production of gas from glucose $\left(10 \mathrm{~g} \mathrm{l}^{-1}\right)$ or gluconic acid $\left(10 \mathrm{~g} \mathrm{l}^{-1}\right)$ in APT broth without added citric acid. Production of ammonia from arginine was investigated in a medium containing tryptose $\left(5 \mathrm{~g} \mathrm{l}^{-1}\right)$, yeast extract $\left(5 \mathrm{~g} \mathrm{l}^{-1}\right)$, potassium phosphate $\left(2 \mathrm{~g} \mathrm{l}^{-1}\right)$, glucose $(0 \cdot 5$ $\left.\mathrm{g}^{-1}\right)$ and arginine $\left(3 \mathrm{~g}^{-1}\right)$ with an initial $\mathrm{pH}$ of $7 \cdot 0$. Reduction of tetrazolium was examined on SBM agar (Wilkinson \& Jones, 1977). The ability to acidify La-broth to a $\mathrm{pH}$ value below 4.15 was investigated at 25 and $30^{\circ} \mathrm{C}$ (Shaw \& Harding, 1984). Growth on acetate agar (Oxoid) was tested under microaerophilic conditions at $30^{\circ} \mathrm{C}$. Nitrate reduction was tested at $30^{\circ} \mathrm{C}$ in Nutrient broth (Oxoid) supplemented with $\mathrm{KNO}_{3}\left(1 \mathrm{~g} \mathrm{l}^{-1}\right)$ and D-xylose $\left(10 \mathrm{~g} \mathrm{l}^{-1}\right)$. The Voges-Proskauer test was performed on Clark \& Lubbs medium (Barrow \& Feltham, 1993) at 25 and $30{ }^{\circ} \mathrm{C}$. The strains were tested for production of acids from carbohydrates and related compounds in API $50 \mathrm{CH}$ strips using API CHL medium according to the instructions of the manufacturer (bioMérieux). The strips were incubated at $30{ }^{\circ} \mathrm{C}$ and read after $1,3,4$ and 10 days. Production and concentration of lactic acid isomers and acetic acid were determined enzymically using D-lactate and L-lactate dehydrogenases and acetyl-CoA synthetase (Boehringer Mannheim) after growth at $30^{\circ} \mathrm{C}$ for $24-68 \mathrm{~h}$ in APT broth with glucose $\left(10 \mathrm{~g} \mathrm{l}^{-1}\right)$ or D-xylose $\left(10 \mathrm{~g} \mathrm{l}^{-1}\right)$ or both carbohydrates (10 $\mathrm{g} \mathrm{l}^{-1}$ each).

Susceptibility towards vancomycin $\left(30 \mu \mathrm{g} \mathrm{g}^{-1}\right)$ was investigated on APT agar. Sensitivity towards the following bacteriocins was tested by the spot-on-lawn method (Ahn \& Stiles, 1990) during growth on APT soft agar (0.75\% agar): nisin (produced by Lactococcus lactis ATCC 11454), divergicin A (produced by Carnobacterium divergens NCFB 2855 ), enterocin P (produced by Enterococcus faecium LMG 19827 and LMG 19828), enterocins L50A and L50B (produced by Enterococcus faecium LMG 19828) and an unidentified enterocin (produced by Enterococcus faecium ATCC 19434 ${ }^{\mathrm{T}}$ ).

Pulsed field gel electrophoresis (PFGE). Lysis of cells, DNA restriction with ApaI and electrophoresis were performed as described by Ojeniyi et al. (1991, 1996). Similarities between PFGE patterns were calculated by use of Jaccard's coefficient $\left(S_{\mathrm{j}}\right)$.

Plasmid profiles. Mini-scale extraction of plasmids was done as described by Klaenhammer (1984) except that samples were not heated at $62{ }^{\circ} \mathrm{C}$ for $1 \mathrm{~h}$ after addition of lysis buffer and that the phenol used for the extraction was not saturated with $\mathrm{NaCl}$. Agarose gel electrophoresis was done on a $0.8 \%$ agarose gel (A-9539; Sigma) in TAE buffer (40 mM Tris acetate, $1 \mathrm{mM}$ EDTA) at $100 \mathrm{~V}$ for $2.5 \mathrm{~h}$. Plasmid sizes were estimated by using Escherichia coli strains V517 and 39R361, which contain plasmids of known sizes (Macrina et al., 1978; Rochelle et al., 1985; Threlfall et al., 1986).

\section{RESULTS AND DISCUSSION}

Three analogous strains of LAB, LMG $19193^{\mathrm{T}}$, LMG 19195 and LMG 19196, isolated from tempoyak (Leisner et al., 2001), could not be identified by wholecell protein fingerprinting and their patterns were distinct from those of all species of LAB available in the database (data not shown). A polyphasic study was performed in order to verify whether these strains represent a novel species.

One representative strain, LMG $19193^{\mathrm{T}}$, was selected for $16 \mathrm{~S}$ rDNA sequence analysis and represented a separate branch in the genus Lactobacillus, linked most closely to the Lactobacillus reuteri phylogenetic group (Fig. 1; Schleifer \& Ludwig, 1995). Highest

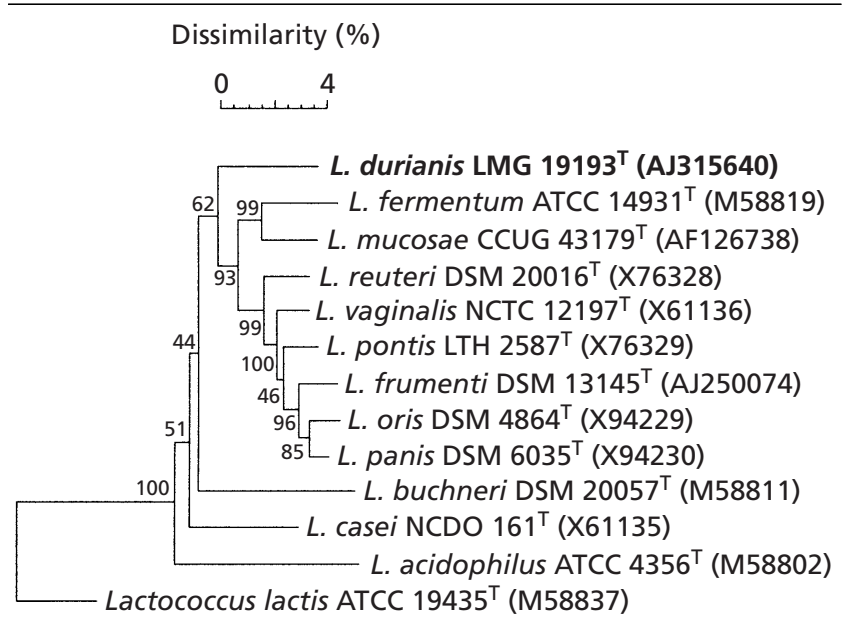

Fig. 1. Distance-matrix tree showing the phylogenetic position of Lactobacillus durianis sp. nov. and related taxa based on $16 \mathrm{~S}$ rDNA sequence comparisons. Lactococcus lactis was used as the outgroup and bootstrap probability values are indicated at the branch-points (100 trees resampled). Accession numbers are given, together with strain designations (where known). L., Lactobacillus. 


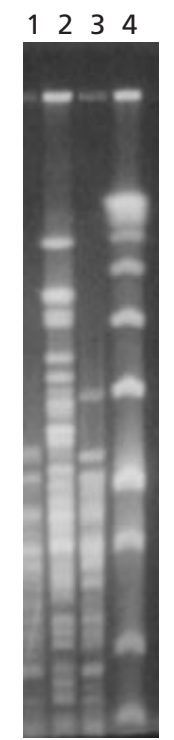

Fig. 2. PFGE patterns of Lactobacillus durianis strains LMG 19193 ${ }^{\top}$ (lane 1), LMG 19196 (2) and LMG 19195 (3). A low-range molecular mass PFG marker (New England Biolabs) is shown in lane 4 . This marker contains 12 fragments with the following sizes: 194.0, 145.5, 97.0, 48.5, 23.1, 9.42, 6.55, 4.36, 2.32, 2.03, 0.56 and $0.13 \mathrm{~kb}$.

similarities of only $93-94 \%$ were obtained with the species Lactobacillus fermentum and related taxa, which clearly indicated that the strain studied represents a novel species (similarity $<97 \%$; Stackebrandt $\&$ Goebel, 1994). DNA-DNA binding values were determined between two representative strains (LMG $19193^{\mathrm{T}}$ and LMG 19196) and a homology value of $82 \%$ confirms that the two strains constitute a single genomic species. The DNA $\mathrm{G}+\mathrm{C}$ contents of these strains were 43.3 and $43.2 \mathrm{~mol} \%$. Plasmid profiling and PFGE of ApaI restriction fragments were performed to type the isolates at the strain level and to detect possible clonal relatedness among the strains. Both genotypic fingerprinting methods revealed that the three strains were clearly differentiated from each other. In the plasmid analysis, LMG $19193^{\mathrm{T}}$ showed three bands; two smaller ones with apparent sizes of 11.5 and $15 \mathrm{~kb}$ and one larger one with an approximate size of $40-45 \mathrm{~kb}$. LMG 19195 contained one large plasmid of approximately 35-40 kb. LMG 19196 did not contain any plasmids. PFGE analyses showed a relatively low degree of homology between the strains, consisting of 55-61\% between LMG $19193^{\mathrm{T}}$ and LMG 19195, 20-23\% between LMG $19193^{\mathrm{T}}$ and LMG 19196 and 29-32\% between LMG 19195 and LMG 19196 (Fig. 2).

All three strains are obligately heterofermentative, as shown by the production of acetic acid from glucose, although no gas is produced from glucose due to the slow and limited growth using this carbohydrate as substrate. Both lactic acid isomers were produced under all circumstances tested. The D-isomer made up
$20 \cdot 1 \pm 5 \cdot 1 \%$ of the total amount of lactic acid produced. Acetic acid was produced in an amount of $44 \pm 2.63 \%$ relative to the total amount of acetic acid and lactic acid. In media with only glucose, growth and acid production were, however, very limited. A large number of additional phenotypic properties were investigated for the novel isolates (summarized below in the description of the species), allowing its differentiation from all obligately heterofermentative species of the genus Lactobacillus (Table 1). The species may be differentiated from obligately homofermentative Lactobacillus species by the production of acid and gas from gluconic acid and by the production of acid from ribose and D-xylose. The novel species may be differentiated from facultatively heterofermentative Lactobacillus species by the production of acetic acid from glucose. In addition, the ability to produce acid from arabinose and xylose but not from cellobiose or sucrose differentiates the species from this group of Lactobacillus species.

The three isolates may also be readily distinguished from obligately heterofermentative Leuconostoc species by the production of both the D- and L-isomers of lactic acid as well as the poor growth and lack of production of gas with glucose as substrate. Differentiation of the species from heterofermentative Weissella species is possible by a combination of the following characteristics: the inability to produce $\mathrm{NH}_{3}$ from arginine, the ability to produce acid from arabinose and xylose and the production of both isomers of lactic acid.

Differentiation of the species from the rod-shaped Carnobacterium species is possible by the ability to grow on acetate, the inability to produce $\mathrm{NH}_{3}$ from arginine or to reduce tetrazolium and the negative reaction in the Voges-Proskauer test. Homofermentative Lactococcus, Enterococcus, Streptococcus, Pediococcus, Lactosphaera, Vagococcus and Tetragenococcus species are easily distinguished by their distinctive coccus-shaped cell morphology.

All three strains were inhibited by nisin produced by Lactococcus lactis ATCC 11454 but not by the enterocins produced by Enterococcus faecium LMG 19827, LMG 19828 and ATCC $19434^{\mathrm{T}}$ or divergicin A produced by Carnobacterium divergens NCFB 2855.

The results of the present study allowed us to assign the strains to a novel species, for which we propose the name Lactobacillus durianis sp. nov. The description is based on results from the present study and data previously reported by Leisner et al. (2001).

\section{Description of Lactobacillus durianis sp. nov.}

Lactobacillus durianis (du.ri.an'is. N.L. adj. durianis of the durian fruit).

Cells are Gram-positive, non-motile and non-sporeforming rods occurring singly, as pairs or in chains (fewer than five cells) in APT broth supplemented with 
Table 1. Differential phenotypic characteristics of Lactobacillus durianis and obligately heterofermentative Lactobacillus species

Data for the majority of species were taken from Hammes \& Vogel (1995) or from Kandler \& Weiss (1986). For certain recently described species, data were obtained from the original species descriptions as indicated. Taxa are indicated as: $1, L$. brevis; $2, L$. buchneri; 3, L. collinoides; 4, L. durianis (data from the present study); 5, L. fermentum; 6, L. fructivorans; 7, L. fructosus; 8, L. frumenti (Müller et al., 2000); 9, L. hilgardii; 10, L. kefiri; 11, L. kunkeei (Edwards et al., 1998); 12, L. lindneri (Back et al., 1996); 13, L. malefermentans; 14, L. mucosae (Roos et al., 2000); 15, L. oris; 16, L. panis (Wiese et al., 1996); 17, L. parabuchneri; 18, L. parakefiri (Takizawa et al., 1994); 19, L. pontis; 20, L. psittaci (Lawson et al., 2001); 21, L. reuteri; 22, L. sanfransiscensis; 23, L. suebicus; 24, L. vaccinostercus; 25, L. vaginalis. Hammes \& Vogel (1995) use the following symbols:,$+>90 \%$ of strains are positive;,$->90 \%$ of strains are negative; $d, 11-89 \%$ of strains are positive; w, weak response; ND, no data available.

\begin{tabular}{|c|c|c|c|c|c|c|c|c|c|c|c|c|c|c|c|c|c|c|c|c|c|c|c|c|c|}
\hline Characteristic & 1 & 2 & 3 & 4 & 5 & 6 & 7 & 8 & 9 & 10 & 11 & 12 & 13 & 14 & 15 & 16 & 17 & 18 & 19 & 20 & 21 & 22 & 23 & 24 & 25 \\
\hline \multicolumn{26}{|l|}{ Growth at: } \\
\hline $15^{\circ} \mathrm{C}$ & + & + & + & + & - & + & + & + & + & + & + & + & + & - & - & - & + & + & + & + & - & + & + & - & - \\
\hline $45^{\circ} \mathrm{C}$ & - & - & - & - & + & - & - & - & - & - & - & - & - & + & $\mathrm{d}$ & + & ND & - & + & + & + & - & $\mathrm{d}$ & - & + \\
\hline $\begin{array}{c}\mathrm{NH}_{3} \text { from } \\
\text { arginine }\end{array}$ & + & + & + & - & + & + & - & + & + & + & - & - & + & + & - & - & + & + & + & - & + & - & ND & - & ND \\
\hline \multicolumn{26}{|l|}{ Acid from: } \\
\hline Arabinose & + & + & + & + & $\mathrm{d}$ & - & - & - & - & $\mathrm{d}$ & - & - & - & $\mathrm{d}$ & + & + & + & + & - & - & + & - & + & + & - \\
\hline Melibiose & + & + & + & - & + & - & - & + & - & + & - & - & - & $\mathrm{d}$ & + & + & + & $\mathrm{d}$ & $\mathrm{d}$ & - & + & - & $\mathrm{d}$ & - & + \\
\hline Ribose & + & + & + & + & + & W & - & + & + & + & - & - & + & + & + & + & + & + & + & - & + & $\mathrm{d}$ & + & + & $\mathrm{d}$ \\
\hline Sucrose & $\mathrm{d}$ & d & - & - & + & $\mathrm{d}$ & - & ND & $\mathrm{d}$ & - & + & - & - & + & + & + & + & - & + & + & + & $\mathrm{d}$ & $\mathrm{d}$ & - & + \\
\hline Xylose & $\mathrm{d}$ & $\mathrm{d}$ & + & + & $\mathrm{d}$ & - & - & - & + & - & - & - & - & $\mathrm{d}$ & + & + & - & - & - & - & - & - & + & + & - \\
\hline
\end{tabular}

glucose, D-xylose or both components. Surface colononies on APT agar with D-xylose or glucose after 3 days of micro-aerophilic incubation at $30{ }^{\circ} \mathrm{C}$ are $1 \mathrm{~mm}$ or less in diameter, round and with smooth surfaces. The colonies are smaller with glucose than with Dxylose (growth is enhanced by replacing glucose with D-xylose). Catalase-negative. Nitrate is not reduced. $\mathrm{NH}_{3}$ is not produced from arginine. The species is obligately heterofermentative. Gas is produced from gluconic acid but not from glucose. $\mathrm{D}(-)$ - and $\mathrm{L}-(+)-$ lactic acid and acetic acid are produced from both glucose and D-xylose. None of the three strains reduces tetrazolium on SBM agar, nor do they grow in Clark \& Lubbs broth used in the Voges-Proskauer test. Able to grow on acetate agar but unable to acidify La-broth below pH 4.15. Growth occurs for all three strains in APT broth with glucose at temperatures ranging from 15 to $42{ }^{\circ} \mathrm{C}$. With D-xylose, growth is observed from 10 to $42^{\circ} \mathrm{C}$ for strains LMG 19195 and LMG 19196 and from 15 to $42^{\circ} \mathrm{C}$ for strain LMG $19193^{\mathrm{T}}$. No growth in the presence of 6.5 or $8 \% \mathrm{NaCl}$. Resistant towards $30 \mu \mathrm{g}$ vancomycin $\mathrm{g}^{-1}$. All three strains are able to produce acid from only a few of the carbohydrates in the API $50 \mathrm{CH}$ kit, including L-arabinose, gluconate (weak reaction), 5-ketogluconate (weak reaction), maltose, ribose, $\mathrm{D}$-xylose and methyl $\beta$-xyloside. Two of the strains (LMG $19193^{\mathrm{T}}$ and LMG 19196) are also able to produce acid from D-glucose and D-lyxose and to hydrolyse aesculin or (LMG $19193^{\mathrm{T}}$ and $\mathrm{LMG}$ 19195) to produce acid from galactose and D-arabinose. One strain (LMG 19193 ${ }^{\mathrm{T}}$ ) produces acid from starch (weak reaction) and another strain (LMG 19196) produces acid from D-arabitol. No acid is produced from adonitol, amygdalin, arbutin, L-arab- itol, cellobiose, dulcitol, erythritol, fructose, D-fucose, L-fucose, gentiobiose, 2-ketogluconate, $N$-acetyl glucosamine, methyl $\alpha$-D-glucoside, glycerol, glycogen, inositol, inulin, lactose, mannitol, mannose, methyl $\alpha$-D-mannoside, melibiose, melizitose, D-raffinose, rhamnose, salicin, sorbitol, L-sorbose, sucrose, Dtagatose, trehalose, D-turanose, xylitol or L-xylose. The DNA G + C content is $43 \cdot 2-43 \cdot 3 \mathrm{~mol} \%$. Features that differentiate $L$. durianis from other obligately heterofermentative Lactobacillus species are listed in Table 1.

Isolated from a Malaysian acid-fermented condiment, tempoyak, made from the durian fruit. The type strain is $\mathrm{LMG} 19193^{\mathrm{T}}\left(=\mathrm{CCUG} 45405^{\mathrm{T}}\right)$.

\section{ACKNOWLEDGEMENTS}

Dr Sten Ebbesen, Institute for Greek and Latin, University of Copenhagen, Denmark, is thanked for his help in naming Lactobacillus durianis. We thank C. Snauwaert for excellent technical assistance.

\section{REFERENCES}

Ahn, C. \& Stiles, M. E. (1990). Antibacterial activity of lactic acid bacteria isolated from vacuum-packaged meats. J Appl Bacteriol 69, 302-310.

Back, W., Bohak, l., Ehrmann, M., Ludwig, W. \& Schleifer, K. H. (1996). Revival of the species Lactobacillus lindneri and the design of a species specific oligonucleotide probe. Syst Appl Microbiol 19, 322-325. Barrow, G. I. \& Feltham, R. K. A. (editors) (1993). Cowan and Steel's Manual for the Identification of Medical Bacteria, 3rd edn. Cambridge: Cambridge University Press.

Coenye, T., Falsen, E., Vancanneyt, M., Hoste, B., Govan, J. R. W., Kersters, K. \& Vandamme, P. (1999). Classification of Alcaligenes 
faecalis-like isolates from the environment and human clinical samples as Ralstonia gilardii sp. nov. Int J Syst Bacteriol 49, 405-413.

Difco Laboratories (1984). In Difco Manual, 10th edn, p. 1071. Detroit: Difco Laboratories.

Edwards, C. G., Haag, K. M., Collins, M. D., Hutson, R. A. \& Huang, Y. C. (1998). Lactobacillus kunkeei sp. nov.: a spoilage organism associated with grape juice fermentations. J Appl Microbiol 84, 698-702.

Ezaki, T., Hashimoto, Y. \& Yabuuchi, E. (1989). Fluorometric deoxyribonucleic acid-deoxyribonucleic acid hybridization in microdilution wells as an alternative to membrane filter hybridization in which radioisotopes are used to determine genetic relatedness among bacterial strains. Int J Syst Bacteriol 39, 224-229.

Hammes, W. P. \& Vogel, R. F. (1995). The genus Lactobacillus. In The Lactic Acid Bacteria, vol. 2, The Genera of Lactic Acid Bacteria, pp. 19-54. Edited by B. J. B. Wood \& W. H. Holzapfel. London: Blackie Academic \& Professional.

Kandler, O. \& Weiss, N. (1986). Genus Lactobacillus Beijerinck 1901 In Bergey's Manual of Systematic Bacteriology, vol. 2, pp. 1209-1234. Edited by P. H. A. Sneath, N. S. Mair, M. E. Sharpe \& J. G. Holt. Baltimore: Williams \& Wilkins.

Klaenhammer, T. R. (1984). A general method for plasmid isolation in lactobacilli. Curr Microbiol 10, 23-28.

Lawson, P. A., Wacher, C., Hansson, I., Falsen, E. \& Collins, M. D. (2001). Lactobacillus psittaci sp. nov., isolated from a hyacinth macaw (Anodorhyncus hyacinthinus). Int J Syst Evol Microbiol 51, 967-970.

Leisner, J. J., Vancanneyt, M., Rusul, G., Pot, B., Lefebvre, K., Fresi, A. \& Tee, L. K. (2001). Identification of lactic acid bacteria constituting the predominant microflora in an acid-fermented condiment (tempoyak) popular in Malaysia. Int J Food Microbiol 63, 149-157.

Macrina, F. L., Kopecko, D. J., Jones, K. R., Ayers, D. J. \& McCowen, S. M. (1978). A multiple plasmid-containing Escherichia coli strain: convenient source of size reference plasmid molecules. Plasmid 1, 417-420.

Mesbah, M., Premachandran, U. \& Whitman, W. B. (1989). Precise measurement of the $\mathrm{G}+\mathrm{C}$ content of deoxyribonucleic acid by highperformance liquid chromatography. Int J Syst Bacteriol 39, 159-167.

Müller, M. R. A., Ehrmann, M. A. \& Vogel, R. F. (2000). Lactobacillus frumenti sp. nov., a new lactic acid bacterium isolated from rye-bran fermentations with a long fermentation period. Int J Syst Evol Microbiol 50, 2127-2133.

Niemann, S., Pühler, A., Tichy, H.-V., Simon, R. \& Selbitschka, W. (1997). Evaluation of the resolving power of three different DNA fingerprinting methods to discriminate among isolates of a natural Rhizobium meliloti population. J Appl Microbiol 82, 477-484.

Ojeniyi, B., Høiby, N. \& Rosdahl, V. T. (1991). Genome fingerprinting as a typing method used on polyagglutinable Pseudomonas aeruginosa isolates from cystic fibrosis patients. APMIS 99, 492-498.

Ojeniyi, B., Wegener, H. C., Jensen, N. E. \& Bisgaard, M. (1996). Listeria monocytogenes in poultry and poultry products: epidemiological investigations in seven Danish abattoirs. J Appl Bacteriol 80, 395-401.

Pitcher, D. G., Saunders, N. A. \& Owen, R. J. (1989). Rapid extraction of bacterial genomic DNA with guanidinium thiocyanate. Lett Appl Microbiol 8, 151-156.

Rochelle, P. A., Fry, J. C., Day, M. J. \& Bale, M. J. (1985). An accurate method for estimating sizes of small and large plasmids and DNA fragments by gel electrophoresis. J Gen Microbiol 132, 53-59.

Roos, S., Karner, F., Axelsson, L. \& Jonsson, H. (2000). Lactobacillus mucosae sp. nov., a new species with in vitro mucus-binding activity isolated from pig intestine. Int J Syst Evol Microbiol 50, 251-258.

Schleifer, K. H. \& Ludwig, W. (1995). Phylogeny of the genus Lactobacillus and related genera. Syst Appl Microbiol 18, 461-467.

Shaw, B. G. \& Harding, C. D. (1984). A numerical taxonomic study of lactic acid bacteria from vacuum-packed beef, pork, lamb and bacon. $J$ Appl Bacteriol 56, 25-40.

Stackebrandt, E. \& Goebel, B. M. (1994). Taxonomic note: a place for DNA-DNA reassociation and $16 \mathrm{~S}$ rRNA sequence analysis in the present species definition in bacteriology. Int $J$ Syst Bacteriol 44, 846-849.

Takizawa, S., Kojima, S., Tamura, S., Fujinaga, S., Benno, Y. \& Nakase, T. (1994). Lactobacillus kefirgranum sp. nov. and Lactobacillus parakefir sp. nov., two new species from kefir grains. Int J Syst Bacteriol 44, 435-439.

Threlfall, E. J., Rowe, B., Ferguson, J. L. \& Ward, L. R. (1986). Characterization of plasmids conferring resistance to gentamicin and apramycin in strains of Salmonella typhimurium phage type 204c isolated in Britain. J Hyg 97, 419-426.

Wiese, B. G., Strohmar, W., Rainey, F. A. \& Diekmann, H. (1996). Lactobacillus panis sp. nov., from sourdough with a long fermentation period. Int J Syst Bacteriol 46, 449-453.

Wilkinson, B. J. \& Jones, D. (1977). A numerical taxonomic survey of Listeria and related bacteria. J Gen Microbiol 98, 399-421. 